\title{
Feasibility of reconstructing paleoatmospheric records of selected alkanes, methyl halides, and sulfur gases from Greenland ice cores
}

\author{
M. Aydin, ${ }^{1}$ M. B. Williams, ${ }^{1}$ and E. S. Saltzman ${ }^{1}$ \\ Received 7 September 2006; revised 29 December 2006; accepted 15 January 2007; published 12 April 2007.
}

[1] Seven short-lived atmospheric trace gases were measured in 25 ice core samples from Summit, Greenland. Samples were selected from contemporaneous sections of fluid- and dry-drilled ice cores to examine what effects using $n$-butyl acetate as the drill fluid would have on the measurements. The gases include three light alkanes, $\mathrm{C}_{2} \mathrm{H}_{6}, \mathrm{C}_{3} \mathrm{H}_{6}$, and $n-\mathrm{C}_{4} \mathrm{H}_{10}$; two methyl halides, $\mathrm{CH}_{3} \mathrm{Cl}$ and $\mathrm{CH}_{3} \mathrm{Br}$; and two sulfur compounds, OCS and $\mathrm{CS}_{2}$, with gas ages from 125 to 325 years before present. Alkane levels are comparable to measurements in modern Arctic air, although $\mathrm{C}_{2} \mathrm{H}_{6}$ exhibits greater variability than expected compared with $\mathrm{C}_{3} \mathrm{H}_{6}$ and $n-\mathrm{C}_{4} \mathrm{H}_{10}$. These results are not consistent with the idea that the alkanes are primarily of anthropogenic origin, suggesting that the ice cores may not truly record a paleoatmospheric signal with respect to these gases. The $\mathrm{CH}_{3} \mathrm{Br}$ results are consistent with previous observations of "excess" $\mathrm{CH}_{3} \mathrm{Br}$ in Greenland firn air. In situ production processes appear to overwhelm the paleoatmospheric signal of this gas. $\mathrm{CH}_{3} \mathrm{Cl}$ exhibits the same effect to a lesser extent. OCS levels are similar to those in Antarctic ice cores and appear to reflect paleoatmospheric levels. $\mathrm{CS}_{2}$ results are similar to the limited database of modern atmospheric measurements. Only $\mathrm{C}_{3} \mathrm{H}_{8}$ and $n-\mathrm{C}_{4} \mathrm{H}_{10}$ exhibit clear evidence of contamination because of the presence of the drill fluid. The results indicate that it is possible to analyze many trace gases in fluid- and dry-drilled ice samples. However, it appears that in situ production may significantly alter the levels of some trace gases in Greenland ice cores.

Citation: Aydin, M., M. B. Williams, and E. S. Saltzman (2007), Feasibility of reconstructing paleoatmospheric records of selected alkanes, methyl halides, and sulfur gases from Greenland ice cores, J. Geophys. Res., 112, D07312, doi:10.1029/2006JD008027.

\section{Introduction}

[2] Air bubbles trapped inside ice cores are a valuable archive of the ancient atmosphere. Although paleoatmospheric histories of greenhouse gases like $\mathrm{CO}_{2}$ and $\mathrm{CH}_{4}$ have been reconstructed from ice cores, much less information exists about the atmospheric variability of lower abundance trace gases such as halocarbons, hydrocarbons, and sulfur gases that have relatively short atmospheric lifetimes, ranging from days to a few years. In this study, we report measurements of $\mathrm{C}_{2}-\mathrm{C}_{4}$ alkanes (ethane, $\mathrm{C}_{2} \mathrm{H}_{6}$; propane, $\mathrm{C}_{3} \mathrm{H}_{8} ; n$-butane, $n-\mathrm{C}_{4} \mathrm{H}_{10}$ ), two methyl halides $\left(\mathrm{CH}_{3} \mathrm{Cl}\right.$ and $\mathrm{CH}_{3} \mathrm{Br}$ ), and two sulfur compounds (OCS and $\mathrm{CS}_{2}$ ) in air extracted from Greenland ice cores. Thirty samples were analyzed from B and D cores drilled to depths of 200 and $3000 \mathrm{~m}$, respectively, as part of the Greenland Ice Sheet Project (GISP2) at Summit, Greenland $\left(72.6^{\circ} \mathrm{N}\right.$, $38.5^{\circ} \mathrm{W}, 3200 \mathrm{~m}$ asl). The shallow B core was dry-drilled, while $n$-butyl acetate $\left(\mathrm{C}_{6} \mathrm{H}_{12} \mathrm{O}_{2}\right)$ was used as the drilling fluid for the $\mathrm{D}$ core. The samples from both cores have contemporaneous gas ages as they were chosen from similar depths. The primary goal of this study is to assess the

\footnotetext{
${ }^{1}$ Department of Earth System Science, University of California, Irvine, California, USA.

Copyright 2007 by the American Geophysical Union. 0148-0227/07/2006JD008027\$09.00
}

feasibility of reconstructing paleoatmospheric levels of short-lived trace gases from dry- and fluid-drilled Greenland ice cores.

[3] There have been two studies of low-molecular-weight alkanes in firn air. $\mathrm{C}_{2} \mathrm{H}_{6}$ and $\mathrm{C}_{3} \mathrm{H}_{8}$ results from an Antarctic shallow firn [Kaspers et al., 2004] and $\mathrm{C}_{2} \mathrm{H}_{6}, \mathrm{C}_{3} \mathrm{H}_{8}$, and $\mathrm{C}_{4} \mathrm{H}_{10}$ measurements in firn air from Summit, Greenland [Worton, 2006], suggest that alkanes are stable in firn and are not prone to in situ artifacts. It has also been shown that there is no photochemical production of alkanes in Greenland snow [Swanson et al., 2002]. The available evidence, albeit limited, suggests that it may be possible to reconstruct a paleoatmospheric record of alkanes from ice core measurements.

[4] Measurements of $\mathrm{CH}_{3} \mathrm{Cl}$ in firn air from Greenland and Antarctica suggest that this gas is preserved in the polar firn air from both hemispheres [Butler et al., 1999; Kaspers et al., 2004; Trudinger et al., 2004]. Trudinger et al. [2004] argue that subtle discrepancies exist between certain Antarctic firn records, which may implicate in situ chemistry. A 300-year atmospheric history of $\mathrm{CH}_{3} \mathrm{Cl}$ was developed based on measurements in Siple Dome ice cores from Antarctica [Aydin et al., 2004]. $\mathrm{CH}_{3} \mathrm{Cl}$ has also been measured in a limited number of samples from another Antarctic ice core [Saito et al., 2006]. The results indicate that $\mathrm{CH}_{3} \mathrm{Cl}$ is stable in polar ice matrices over centennial timescales. 
[5] $\mathrm{CH}_{3} \mathrm{Br}$ exhibits different behavior in firn air from the two hemispheres. Antarctic firn air appears to record paleoatmospheric $\mathrm{CH}_{3} \mathrm{Br}$ levels. Firn air profiles from several Antarctic sites show $\mathrm{CH}_{3} \mathrm{Br}$ levels increasing through the twentieth century in reasonable agreement with estimates of anthropogenic emissions [Butler et al., 1999; Sturges et al., 2001a; Trudinger et al., 2004]. Antarctic ice core measurements in Siple Dome demonstrate that $\mathrm{CH}_{3} \mathrm{Br}$ is stable in Antarctic ice on timescales of hundreds of years and exhibits levels consistent with those in firn air [Saltzman et al., 2004]. In contrast, results from Tunu, Greenland, and Devon Island, Canada, indicate enrichment of $\mathrm{CH}_{3} \mathrm{Br}$ in firn air relative to atmospheric levels [Butler et al., 1999; Sturges et al., 2001a]. So far, the enrichment observed in the Northern Hemisphere firn sites has not been explained, but Swanson et al. [2002] observed photochemical production of $\mathrm{CH}_{3} \mathrm{Br}$ in Greenland surface snow, providing the first direct evidence of possible artifacts because of in situ chemistry.

[6] OCS is the only sulfur gas that has been measured in polar firn air and ice cores. Firn air results from Antarctica and Canada suggest that an atmospheric OCS record is preserved in both hemispheres [Sturges et al., 2001b]. More recently, Antarctic ice core and firn air measurements have been used to reconstruct the atmospheric history of OCS over the last 400 years [Aydin et al., 2002; Montzka et al., 2004]. To date, there are no published measurements of $\mathrm{CS}_{2}$ in firn air or ice cores.

\section{Methods}

\subsection{Ice Core Dating}

[7] At polar glacial sites, the vertical transport of gases in firn is determined primarily by molecular diffusion, gravitational settling, and to a lesser degree by wind pumping and convection [Schwander et al., 1993]. The aging of various gases in the firn occurs at slightly different rates that can be estimated from their respective molecular weights and diffusivities [Schwander et al., 1993, 1997]. Below the bubble close-off depth, all gases age at the same rate, determined by the snow accumulation rate. A gas age at bubble close off is not a true age but rather a mean diffusive age that is always younger than the surrounding ice at close off. Lighter, more diffusive gases have a younger mean age and a narrower gas age distribution profile than heavier, less diffusive ones. In the calculation of the mean gas ages in this study, we determine an ice age-gas age difference (delta age) specific to each gas at pore close-off depth and subtract this delta age from the ice ages through the length of the core.

[8] The ice core samples analyzed in this study are from a depth range of 98.7-137.1 $\mathrm{m}$ for GISP2 B and 112.9$145.9 \mathrm{~m}$ for GISP2 D. At the D core site, the pore close off is at $72 \mathrm{~m}$, and the mean methane age at this depth is 9 years with a standard deviation of 5.5 years for the age distribution [Schwander et al., 1997]. The species-specific gas ages and the standard deviations of the age distributions at pore close off are calculated by scaling the mean methane age with the diffusivity of each gas relative to methane [Schwander et al., 1997]. Subtracting these gas ages from the ice age at close off yields delta ages of 194, 191, 188,
193, 191, 192, and 189 years for $\mathrm{C}_{2} \mathrm{H}_{6}, \mathrm{C}_{3} \mathrm{H}_{8}, n-\mathrm{C}_{4} \mathrm{H}_{10}$, $\mathrm{CH}_{3} \mathrm{Cl}, \mathrm{CH}_{3} \mathrm{Br}, \mathrm{OCS}$, and $\mathrm{CS}_{2}$, respectively. The standard deviations of age distributions are $8,11,12,9,11,9$, and 12 years for these gases in the same order. The gas ages at sampling depths for the length of the core are calculated by subtracting the delta ages from the ice ages for the GISP2 D core determined by layer counting [Alley et al., 1993; Meese et al., 1994; Meese et al., special CRREL report, 94-1 US], resulting in a slightly different mean age for each gas species at the same depth. The ice ages for the GISP2 B are calculated by adding a 5-year offset to the ice ages of the $\mathrm{D}$ core at the same depth. This offset is based on a comparison of ice ages determined for both cores by continuous measurements of various major ions [Mayewski et al., 1990, 1997; Taylor et al., 1996; Yang et al., 1995]. Calculated gas ages are reported as years before present (BP) referenced to the calendar year 2000.

[9] In the discussion of OCS results, GISP2 measurements are compared with previously published results from Siple Dome, Antarctica. The Siple Dome gas ages were obtained with a similar approach to what is used in this study. Details of the age calculations for that core are given in the works by Aydin et al. [2002] and Montzka et al. [2004]. Those gas ages are used unchanged in the current study.

\subsection{Ice Core Extraction}

[10] The air is liberated from the ice core samples using a dry-extraction technique, in which ice is mechanically shredded under vacuum [Etheridge et al., 1988; Sowers and Jubenville, 2000]. The extraction chamber is a cylindrical electropolished stainless steel tube, which is $14.5 \mathrm{~cm}$ in diameter and $20 \mathrm{~cm}$ in length. The chamber ends are conflat flanges sealed by copper gaskets, and a bellows valve is welded to the flange on one end for transferring gas. A flat stainless steel grater is mounted lengthwise in the chamber. Since dry-extraction requires that the samples stay frozen during extraction, the chamber is mounted inside a chest freezer and connected to a motorized piston providing a linear motion of $13 \mathrm{~cm}$ at $1 \mathrm{~Hz}$. When not in motion, the extraction chamber is connected to a stainless steel vacuum line via a flexible stainless steel bellows. All valves on the vacuum line are stainless steel bellows valves with alloy or copper valve tips.

[11] In preparation for the extraction, the ice core sample and the extraction chamber are precooled to -40 or $-50^{\circ} \mathrm{C}$. We found that the extraction process worked successfully at either temperature for the gases presented here. The outer 2-3 $\mathrm{mm}$ are shaved off, and the sample is placed on the grater inside the chamber. After loading the sample, the chamber is pumped down to $10^{-2}$ torr and repeatedly flushed with clean $\mathrm{N}_{2}$ to remove residual air. The chamber is then disconnected from the vacuum line, and the motorized piston is operated for $15 \mathrm{~min}$. The ice core shreds as it slides back and forth over the grater, liberating $70-80 \%$ of the air trapped in the sample. The GISP2 samples were $300-600 \mathrm{~g}$, yielding $30-60 \mathrm{~cm}^{3}$ standard temperature and pressure (STP) of air. After extraction, the chamber is reconnected to the vacuum line, and the air is condensed into a 76-cm long, 1/4" outside diameter (OD) stainless steel tube immersed in liquid helium. It takes about $4 \mathrm{~min}$ to 
cryogenically pump $>95 \%$ of the sample into the tube. The analysis of the extracted air starts $10 \mathrm{~min}$ after recovery.

\subsection{Gas Analysis}

[12] The air extracted from the ice cores is analyzed using gas chromatography (GC) with mass spectrometric detection (HP 5890/Micromass Autospec Ultima). The sample is cryogenically focused on a 1/8" OD glass bead trap immersed in liquid nitrogen. The size of the sample is determined by measuring the pressure change on a calibrated volume downstream of the cryotrap. An aliquot of isotopelabeled gas standard $\left(30 \mathrm{~cm}^{3} \mathrm{STP}\right)$ is added to the cryotrap to provide an internal reference for quantitation. The mixture of condensable gases from the sample and the internal standard are then transferred in a helium stream to a fused silica loop in liquid nitrogen and thermally injected onto the GC column. The GC oven is programmed to stay isothermal at $-50^{\circ} \mathrm{C}$ for $3 \mathrm{~min}$, ramp to $-40^{\circ} \mathrm{C}$ at $5^{\circ} \mathrm{C} / \mathrm{min}$, followed by a $15^{\circ} \mathrm{C} / \mathrm{min}$ ramp to $30^{\circ} \mathrm{C}$ and a $30^{\circ} \mathrm{C} / \mathrm{min}$ ramp to $120^{\circ} \mathrm{C}$.

[13] The mass spectrometer is operated in selected ion mode at a mass resolution of $6000(\mathrm{M} / \Delta \mathrm{M}$ at $5 \%)$, using ion fragments of deuterium (D-) labeled dodecane as the lock masses. At this mass resolution, halocarbons are fully resolved from hydrocarbons at the same mass to charge ratio [Engen et al., 1998, 1999]. D-labeled dodecane is used because its ion fragments do not interfere with fragments from undeuterated atmospheric hydrocarbons, from ${ }^{13} \mathrm{C}$-labeled hydrocarbons used as internal standards, or from halocarbons.

[14] The primary standards used for the calibration of the system are prepared at University of California, Irvine (UCI), in Aculife-treated aluminum cylinders (Scott Specialty Gases) pressurized with dry $\mathrm{N}_{2}$. Each standard cylinder contains a parts per billion (ppb)- level mixture of all the unlabeled trace gases, which are added into the cylinders by volumetric injection of commercially purchased pure compounds. One exception is $\mathrm{CS}_{2}$. Since pure $\mathrm{CS}_{2}$ is in liquid phase at laboratory temperature and pressure, it is prediluted to parts per thousand levels in a separate aluminum cylinder, which is used in the preparation of the ppb-level standards. Currently, there are three of these primary standards that were prepared in 2003, 2004, and 2005 calendar years. All three cylinders are used to calibrate a fourth standard cylinder, prepared at ppb-level in the same manner as the primary standards but containing the isotope-labeled analogues of the same trace gases. The isotope-labeled gas standard contains ${ }^{13} \mathrm{C}$-labeled $\mathrm{C}_{2} \mathrm{H}_{6}$, $\mathrm{C}_{3} \mathrm{H}_{8}, n-\mathrm{C}_{4} \mathrm{H}_{10}$, OCS, and $\mathrm{CS}_{2}$ as well as fully deuterated $\mathrm{CH}_{3} \mathrm{Cl}$ and $\mathrm{CH}_{3} \mathrm{Br}$. CFC-12 is also measured but not calibrated by isotope dilution. The stability of the trace gases in the pressurized cylinders is monitored by cross calibrating the standard tanks twice a year.

[15] System calibration and routine analyses with isotope dilution are carried out, using parts per trillion (ppt)- level working standards. Both the unlabeled and labeled working standards are prepared at near ambient levels by diluting the ppb-level primary standards with humid $\mathrm{N}_{2}$ in electropolished stainless steel flasks. New working standards are prepared every 3-4 weeks to avoid compromising their stability in the flasks. The use of isotope-labeled internal standards compensates for drift in the mass spectrometer response and run-to-run variations in chromatographic peak shape.

\section{Data}

[16] Thirty ice core samples were analyzed as part of this project with 15 samples each from the GISP2 B and D cores. All data are corrected for gravitational effects that act to enrich the air in the bottom of the firn with respect to gases that have higher molecular weights than air. In the order of size, the gravitational corrections are $0.04 \%, 0.5 \%, 0.7 \%$, $1.0 \%, 1.1 \%, 1.7 \%$, and $2.3 \%$ for $\mathrm{C}_{2} \mathrm{H}_{6}, \mathrm{C}_{3} \mathrm{H}_{8}, \mathrm{CH}_{3} \mathrm{Cl}$, $n-\mathrm{C}_{4} \mathrm{H}_{10}, \mathrm{OCS}, \mathrm{CS}_{2}$, and $\mathrm{CH}_{3} \mathrm{Br}$, respectively. In addition to the gases presented here, CFC-12 was also measured as an indicator of contamination by modern air due either to air trapped in fractures in the ice sample or to the leaks during the handling of the gas sample. Three GISP2 B and two GISP2 D samples had exceptionally high mixing ratios of CFC-12 (>10 ppt) and were not included in this data set, lowering the total number of samples to 25 . The average CFC-12 level is $2 \pm 3 \mathrm{ppt}(1 \sigma)$ for the 12 GISP2 B samples and less than $1 \pm 2 \mathrm{ppt}(1 \sigma)$ for the 13 GISP2 D samples. Nitrogen blank runs were always CFC-12 free, and barometric leak checks did not indicate any problems with the integrity of the vacuum systems during extraction and analyses. We suggest that the low levels of CFC-12 measured in most ice core samples may reflect diffusion of air along small fractures in the ice core, with the presumption that the preindustrial atmosphere was $\mathrm{CFC}$ free.

[17] Since CFC-12 currently measures over $500 \mathrm{ppt}$ in the atmosphere [Walker et al., 2000] and potentially higher in storage freezers where ice cores are stored, even a minute amount of modern air trapped in a fracture can cause a nonzero CFC-12 measurement. For example, $100 \mu \mathrm{l} \mathrm{STP} \mathrm{of}$ modern air at 500 ppt mixed with $50 \mathrm{~cm}^{3}$ STP of CFC-free air from an ice core will result in a $1 \mathrm{ppt}$ measurement. If the ice core and modern air mixing ratios were $100 \mathrm{ppt}$ and $1000 \mathrm{ppt}$, respectively, for a given gas, the same amount of intrusion would result in a $101.8 \mathrm{ppt}$ measurement. Thus gases with large anthropogenic components should be the most sensitive to contamination by modern air. In this study, none of the gases, including the alkanes, display any correlation with the nonzero CFC-12 measurements. We conclude that the existence of CFC-12 in some ice core samples has no significant impact on the data presented here.

[18] Analytical uncertainties for all mixing ratios in the subsequent sections and tables are reported as $\pm 1 \sigma$. One factor that contributes to the analytical uncertainty is the variability in the background levels of each trace gas in the ice core extraction system as determined by $\mathrm{N}_{2}$ blank runs, acquired before and after an ice core sample is shredded. For this purpose, about $30 \mathrm{~cm}^{3}$ STP of clean $\mathrm{N}_{2}$ is isolated in the extraction chamber for the same amount of time it takes to shred an ice core sample. The size of the blank correction for each sample is determined from the average of $\mathrm{N}_{2}$ blanks taken before and after shredding the sample. The preshred $\mathrm{N}_{2}$ blanks are isolated in the chamber over a whole piece of ice core sample, and the postshred blanks are exposed to the shredded sample. The extraction and analyses of the $\mathrm{N}_{2}$ blanks are carried out following exactly the same procedures as a sample to capture the combined background level 
Table 1. Molar Ratio of Analytical Blank to Ice Core Signal for Various Trace Gases in Percentages

\begin{tabular}{lccr}
\hline & GISP2 B & GISP2 D & Overall \\
\hline $\mathrm{C}_{2} \mathrm{H}_{6}$ & $3.3 \pm 0.9$ & $3.5 \pm 0.6$ & $3.4 \pm 0.8$ \\
$\mathrm{C}_{3} \mathrm{H}_{8}$ & $8.3 \pm 1.4$ & $7.8 \pm 1.9$ & $8.0 \pm 1.6$ \\
$n-\mathrm{C}_{4} \mathrm{H}_{10}$ & $8.5 \pm 1.0$ & $7.8 \pm 2.4$ & $8.2 \pm 1.9$ \\
$\mathrm{CH}_{3} \mathrm{Cl}$ & $2.0 \pm 1.1$ & $2.6 \pm 2.8$ & $2.3 \pm 2.1$ \\
$\mathrm{CH}_{3} \mathrm{Br}$ & $1.4 \pm 1.1$ & $0.8 \pm 0.6$ & $1.0 \pm 0.9$ \\
$\mathrm{OCS}$ & $2.7 \pm 0.4$ & $6.7 \pm 4.5$ & $4.8 \pm 3.8$ \\
$\mathrm{CS}_{2}$ & $13.3 \pm 7.2$ & $13.7 \pm 6.7$ & $13.5 \pm 6.8$ \\
\hline
\end{tabular}

contamination in both the extraction and analytical systems as they apply to an ice core sample. Ice core samples, preshred, and postshred blanks are all wet, containing roughly the same amount of humidity because of sublimation from the ice surface. The samples are analyzed without any chemical or physical dehumidification procedure.

[19] The size of the blank correction is only 1 and $2 \%$ of the signal for the two methyl halides, over $3 \%$ for $\mathrm{C}_{2} \mathrm{H}_{6}$, about $8 \%$ for $\mathrm{C}_{3} \mathrm{H}_{8}$ and $n-\mathrm{C}_{4} \mathrm{H}_{10}, 5 \%$ for OCS, and close to $14 \%$ for $\mathrm{CS}_{2}$ (Table 1). The blank correction for $\mathrm{CS}_{2}$ is large and quite variable. For the remainder of the compounds, the blank corrections have a minor impact on the overall analytical uncertainty. For example, the $\mathrm{C}_{3} \mathrm{H}_{8}$ and $n-\mathrm{C}_{4} \mathrm{H}_{10}$ blanks are relatively high compared to signal size, but they are reproducible. $\mathrm{CH}_{3} \mathrm{Cl}, \mathrm{CH}_{3} \mathrm{Br}$, and OCS blanks are highly variable but equal only a small fraction of the signal. There is no difference in the blanks between the dry-drilled B core and the fluid-drilled D core except for OCS. OCS blanks for the $\mathrm{D}$ core samples are higher on average and display more variability. On the basis of the blank variability observed for the GISP2 data set, the detection limits $(3 \sigma)$ of our system for an ice core sample of average size $\left(\sim 35 \mathrm{~cm}^{3}\right.$ STP of air $)$ are $92,69,43,30,2.1,31$, and 3.3 ppt for $\mathrm{C}_{2} \mathrm{H}_{6}, \mathrm{C}_{3} \mathrm{H}_{8}, \mathrm{C}_{4} \mathrm{H}_{10}$, $\mathrm{CH}_{3} \mathrm{Cl}, \mathrm{CH}_{3} \mathrm{Br}$, OCS, and $\mathrm{CS}_{2}$, respectively.

[20] Analytical precision is the second factor that contributes significantly to the overall uncertainties reported for the current data set. The precision is determined from the reproducibility of the calibration runs for the analytical system as well as the variation in factors inherent to the gas extraction process such as ice core sample size, extraction efficiency, and the concentration of each particular gas in the extracted air.

[21] The accuracy of the analysis includes uncertainties arising from standard preparation in addition to the factors that affect the precision. The accuracy of the standards that are used in calibration of the system is estimated at $2-3 \%$ on the basis of the reproducibility of primary standard tanks prepared at the UCI. Informal intercalibration efforts between our laboratory at the UCI and NOAA/ESRL-GMD for $\mathrm{OCS}, \mathrm{CH}_{3} \mathrm{Cl}$, and $\mathrm{CH}_{3} \mathrm{Br}$ show agreement to within $2-3 \%$ [Aydin et al., 2004; Montzka et al., 2004] (S. A. Montzka, personal communication) or within the range of our estimated accuracy.

\section{Results and Discussion}

\subsection{Alkanes}

\subsubsection{Ethane}

[22] Modern atmospheric $\mathrm{C}_{2} \mathrm{H}_{6}$ levels in the Northern Hemisphere range from 0.3 to $3.5 \mathrm{ppb}$, with the highest mixing ratios occurring at high latitudes [Kanakidou et al.,
1991; Rudolph, 1995; Boissard et al., 1996]. Rudolph [1995] estimates the modern annual average $\mathrm{C}_{2} \mathrm{H}_{6}$ mixing ratio in the Arctic lower troposphere at $2.0-2.5 \mathrm{ppb}$, with a steep latitudinal gradient between midlatitudes and the Arctic. Land-based measurements at Fraserdale $\left(50^{\circ} \mathrm{N}\right.$, $\left.82^{\circ} \mathrm{W}\right)$ and Alert $\left(82^{\circ} \mathrm{N}, 62^{\circ} \mathrm{W}\right)$, Canada, Rorvik $\left(57^{\circ} \mathrm{N}\right.$, $\left.12^{\circ} \mathrm{E}\right)$, Sweden, and Pallas $\left(68^{\circ} \mathrm{N}, 24^{\circ} \mathrm{E}\right)$, Norway, show wintertime average levels in the $2.2-2.7 \mathrm{ppb}$ range and mean summertime levels in the $0.8-1.0 \mathrm{ppb}$ range [Gautrois et al., 2003; Jobson et al., 1994; Laurila and Hakola, 1996; Lindskog and Moldanova, 1994]. Airborne measurements from the lower troposphere in the high northern latitudes show wintertime $\mathrm{C}_{2} \mathrm{H}_{6}$ levels of 2.0-2.5 ppb [Anderson et al., 1993; Blake et al., 2003; Penkett et al., 1993] and summertime levels at Summit, Greenland are $0.7 \mathrm{ppb}$ [Swanson et al., 2002]. $\mathrm{C}_{2} \mathrm{H}_{6}$ is removed from the atmosphere by reaction with hydroxyl radical $(\mathrm{OH})$, with a mean annual lifetime of about a few months [Blake et al., 2003; Boissard et al., 1996]. The atmospheric burden of $\mathrm{C}_{2} \mathrm{H}_{6}$ is consistent with the estimated emissions from biomass burning and natural gas losses, with minor contributions from wetlands, soils, oceans, and automotive as well as industrial emissions [Rudolph, 1995].

[23] $\mathrm{C}_{2} \mathrm{H}_{6}$ levels in the GISP2 ice core samples range from 0.96 to $2.53 \mathrm{ppb}$ with a mean of $1.62 \pm 0.43 \mathrm{ppb}$ (Figure 1 and Table 2). In five pairs of contemporaneous samples from the B and D cores at 180, 192, 204, 222, and 283 BP (given ages are for D core samples), the agreement is very good. Only the pair at $275 \mathrm{BP}$ displays a large difference, with one fluid-drilled sample having $2.04 \mathrm{ppb}$ of $\mathrm{C}_{2} \mathrm{H}_{6}$ compared with 1.15 and $1.25 \mathrm{ppb}$ of $\mathrm{C}_{2} \mathrm{H}_{6}$ in the two adjacent dry-drilled samples. The highest $\mathrm{C}_{3} \mathrm{H}_{8}$ and $n-\mathrm{C}_{4} \mathrm{H}_{10}$ mixing ratios in the entire data set are also observed in the same fluid-drilled sample from $275 \mathrm{BP}$ (Figure 1). $\mathrm{C}_{3} \mathrm{H}_{8}$ and $n-\mathrm{C}_{4} \mathrm{H}_{10}$ measurements appear to be more sensitive to the effects of drill-fluid contamination as discussed in the following sections. It is likely that this sample represents an extreme case of drill-fluid contamination.

\subsubsection{Propane}

[24] Propane levels in the modern atmosphere are generally about $30 \%$ of atmospheric ethane levels, although data are more limited for propane, especially at high latitudes of the Northern Hemisphere [Poisson et al., 2000]. $\mathrm{C}_{3} \mathrm{H}_{8}$ levels at Fraserdale, Canada $\left(50^{\circ} \mathrm{N}, 82^{\circ} \mathrm{W}\right)$ averaged $0.08-$ $1.22 \mathrm{ppb}$ from summer to winter over the period 1990 1992 [Jobson et al., 1994], while at Alert $\left(82^{\circ} \mathrm{N}, 62^{\circ} \mathrm{W}\right)$, Canada over the period 1989-1996, the mean $\mathrm{C}_{3} \mathrm{H}_{8}$ levels were about $0.71 \mathrm{ppb}$ with a summer to winter range of 0.16-1.42 ppb [Gautrois et al., 2003]. At Rorvik $\left(57^{\circ} \mathrm{N}\right.$, $12^{\circ} \mathrm{E}$ ), Sweden, wintertime $\mathrm{C}_{3} \mathrm{H}_{8}$ levels in 1989-1990 averaged about $1.27 \mathrm{ppb}$ and dropped to $0.24 \mathrm{ppb}$ in summer [Lindskog and Moldanova, 1994], and at Pallas $\left(68^{\circ} \mathrm{N}, 24^{\circ} \mathrm{E}\right)$, Norway in $1993-1994$, the mean $\mathrm{C}_{3} \mathrm{H}_{8}$ level was $0.6 \mathrm{ppb}$, with a variability of $0.14-1.20 \mathrm{ppb}$ between summer and winter [Laurila and Hakola, 1996]. Airborne measurements from the high northern latitudes show wintertime $\mathrm{C}_{3} \mathrm{H}_{8}$ levels near $1 \mathrm{ppb}$, suggesting mean annual levels of roughly $0.5 \mathrm{ppb}$ [Anderson et al., 1993; Blake et al., 2003; Penkett et al., 1993]. $\mathrm{C}_{3} \mathrm{H}_{8}$ has an atmospheric lifetime of a few weeks [Blake et al., 2003].

[25] The range of $\mathrm{C}_{3} \mathrm{H}_{8}$ levels in the dry- and fluiddrilled ice core samples are $0.32-0.49$ and $0.28-1.0 \mathrm{ppb}$, 

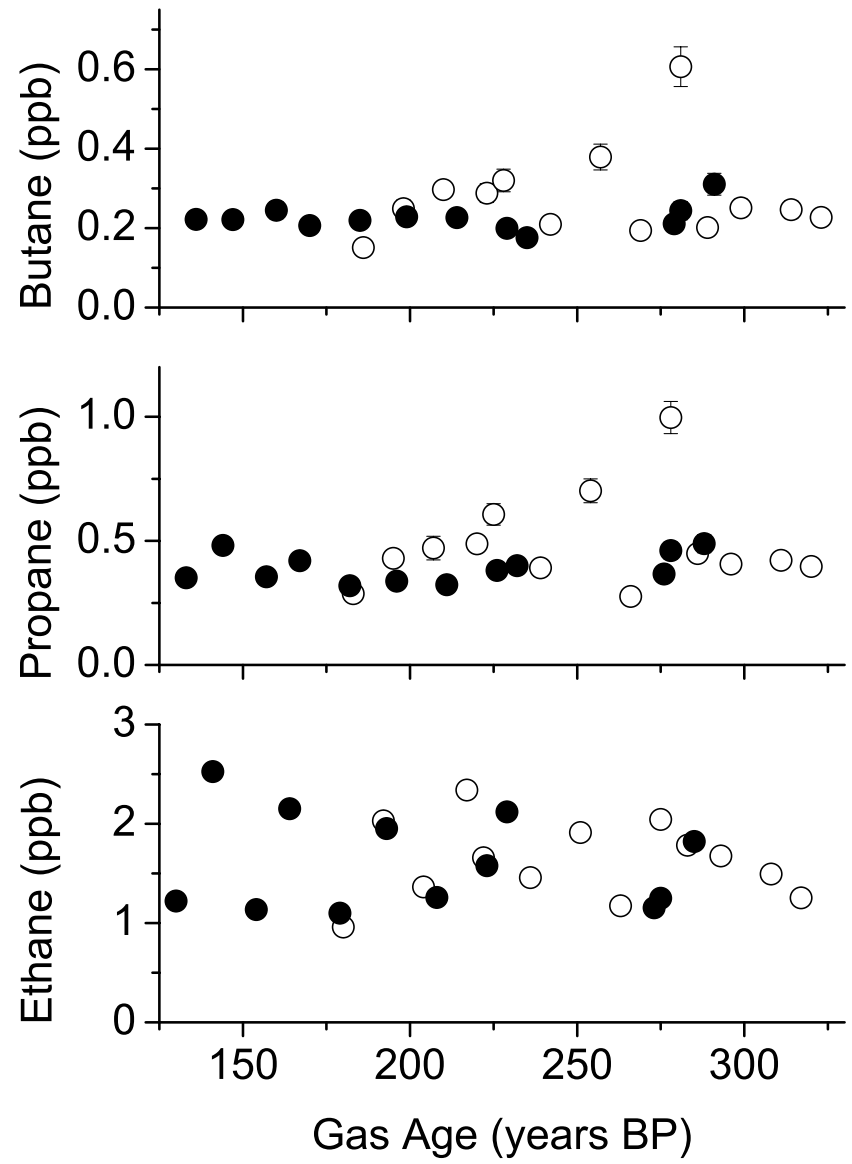

Figure 1. $\mathrm{C}_{2} \mathrm{H}_{6}, \mathrm{C}_{3} \mathrm{H}_{8}$, and $n-\mathrm{C}_{4} \mathrm{H}_{10}$ mixing ratios in Greenland ice core samples from the dry-drilled GISP2 B core $(\bullet)$ and the fluid-drilled GISP2 D core $(O)$. Error bars are shown only when they are larger than the symbols.

respectively (Figure 1). There are several samples for which there is excellent agreement between the two ice cores. However, there is an overall tendency for $\mathrm{C}_{3} \mathrm{H}_{8}$ in the fluiddrilled samples to be higher than contemporary samples of the dry-drilled core. The presence of the drilling fluid, which probably penetrated the ice along fractures that later healed, appear to contaminate $\mathrm{C}_{3} \mathrm{H}_{8}$ as well as the $n-\mathrm{C}_{4} \mathrm{H}_{10}$ results. For the $\mathrm{B}$ core, the $\mathrm{C}_{3} \mathrm{H}_{8}$ levels are roughly 20$30 \%$ of the corresponding $\mathrm{C}_{2} \mathrm{H}_{6}$ measurements, similar to their modern relative abundance in the Northern Hemisphere, and exhibit a standard deviation of only $15 \%$ unlike the highly variable $\mathrm{C}_{2} \mathrm{H}_{6}$ (Table 2). Overall, ice core $\mathrm{C}_{3} \mathrm{H}_{8}$ levels and $\mathrm{C}_{3} \mathrm{H}_{8} / \mathrm{C}_{2} \mathrm{H}_{6}$ ratios are similar to those in modern high-latitude Northern Hemispheric air.

\subsection{3. n-Butane}

[26] $n-\mathrm{C}_{4} \mathrm{H}_{10}$ levels in the Arctic lower troposphere range from about $0.3-0.5 \mathrm{ppb}$ during winter to less than $0.2 \mathrm{ppb}$ during summertime based on airborne studies [Anderson et al., 1993; Blake et al., 2003; Penkett et al., 1993]. Landbased measurements at high latitudes vary from $0.4-0.8 \mathrm{ppb}$ in winter to 40-50 ppt in summer [Gautrois et al., 2003; Jobson et al., 1994; Laurila and Hakola, 1996; Lindskog and Moldanova, 1994]. $n-\mathrm{C}_{4} \mathrm{H}_{10}$ is short-lived, with a mean annual lifetime of about 10 days to a few weeks [Blake et al., 2003]. $n-\mathrm{C}_{4} \mathrm{H}_{10}$ levels in the dry- and wet-drilled ice core samples range from 0.2 to $0.3 \mathrm{ppb}$ and 0.2 to $0.6 \mathrm{ppb}$, respectively (Figure 1). The pattern of variability of $n-\mathrm{C}_{4} \mathrm{H}_{10}$ in the ice is very similar to that of $\mathrm{C}_{3} \mathrm{H}_{8}$, with a similar tendency for the fluid-drilled core to have elevated levels (Table 2).

[27] $\mathrm{C}_{2} \mathrm{H}_{6}$ exhibits a surprisingly high level of variability in the ice that is not shared by $\mathrm{C}_{3} \mathrm{H}_{8}$ and $n-\mathrm{C}_{4} \mathrm{H}_{10}$. This variability in the $\mathrm{C}_{2} \mathrm{H}_{6}$ signal is apparently a real feature of the ice chemistry, as evidenced by the covariance between the two ice cores. There is no evidence of severe analytical artifacts as the signal for the alkanes in the samples are well above the analytical blanks, and there are no obvious problems associated with extraction of the gas from the ice. There is evidence for drill-fluid contamination of $\mathrm{C}_{3} \mathrm{H}_{8}$ and $n-\mathrm{C}_{4} \mathrm{H}_{10}$ in some samples, but this is not severe.

[28] The observed levels of $\mathrm{C}_{2} \mathrm{H}_{6}, \mathrm{C}_{3} \mathrm{H}_{8}$, and $n-\mathrm{C}_{4} \mathrm{H}_{10}$ are well within the range observed in the modern atmosphere. The ratios of the various alkanes are also generally consistent with an atmospheric origin for the ice core measurements. The atmospheric ratios of these gases presumably reflect the combined effect of the relative strength of their sources and their $\mathrm{OH}$ rate constants. If the ice core signal were a result of some photochemical or biological process in firn or ice, one would expect to observe anomalous alkane ratios in the ice bubbles. In an analysis of firn air from Greenland, Worton [2006] reported that the amount of $\mathrm{C}_{2} \mathrm{H}_{6}, \mathrm{C}_{3} \mathrm{H}_{8}$, and $n-\mathrm{C}_{4} \mathrm{H}_{10}$ over Greenland peaked in the 1990 s at levels up to two times higher than 1950 values. Worton [2006] also noted a considerable but relatively smaller drop in light alkane levels since the 1990s, which they attribute to changes in hydrocarbon emissions. However, current budget estimates attribute most of the $\mathrm{C}_{2} \mathrm{H}_{6}$ in the Arctic region to natural gas losses [Olivier et al., 1996; Rudolph, 1995], and global natural gas consumption has nearly doubled between 1980 and 2004 (http://www.eia. doe.gov/emeu/international/). Assuming that the nonanthropogenic source terms in the $\mathrm{C}_{2} \mathrm{H}_{6}$ budget have not changed, it is expected that preindustrial atmospheric $\mathrm{C}_{2} \mathrm{H}_{6}$ levels should have been considerably lower than modern levels. In this regard, the GISP2 ice core results are not consistent with current budget estimates.

\subsection{Methyl Chloride and Methyl Bromide}

[29] $\mathrm{CH}_{3} \mathrm{Cl}$ is the most abundant halocarbon in the troposphere, with a global average mixing ratio of $550 \pm$ $30 \mathrm{ppt}$ and an atmospheric lifetime estimated at 1.3 years [Keene et al., 1996; Khalil and Rasmussen, 1999, 2000; Montzka et al., 2003a; Moore et al., 1996]. Firn air measurements from Antarctica and Greenland suggest that the atmospheric levels of $\mathrm{CH}_{3} \mathrm{Cl}$ remained within $10 \%$ of

Table 2. Average Mixing Ratio of All Compounds Reported as ppt With $\pm 1 \sigma$ of Measured Quantities

\begin{tabular}{llll}
\hline & \multicolumn{1}{c}{ GISP2 B } & \multicolumn{1}{c}{ GISP2 D } & \multicolumn{1}{c}{ Overall } \\
\hline $\mathrm{C}_{2} \mathrm{H}_{6}$ & $1606 \pm 491$ & $1627 \pm 393$ & $1617 \pm 434$ \\
$\mathrm{C}_{3} \mathrm{H}_{8}$ & $390 \pm 60$ & $486 \pm 191$ & $440 \pm 149$ \\
$n-\mathrm{C}_{4} \mathrm{H}_{10}$ & $226 \pm 33$ & $278 \pm 115$ & $253 \pm 89$ \\
$\mathrm{CH}_{3} \mathrm{Cl}$ & $692 \pm 299$ & $717 \pm 384$ & $705 \pm 339$ \\
$\mathrm{CH}_{3} \mathrm{Br}$ & $59 \pm 34$ & $105 \pm 198$ & $83 \pm 144$ \\
$\mathrm{OCS}$ & $334 \pm 19$ & $317 \pm 23$ & $325 \pm 23$ \\
$\mathrm{CS}_{2}$ & $10 \pm 5$ & $10 \pm 8$ & $10 \pm 6$ \\
\hline
\end{tabular}



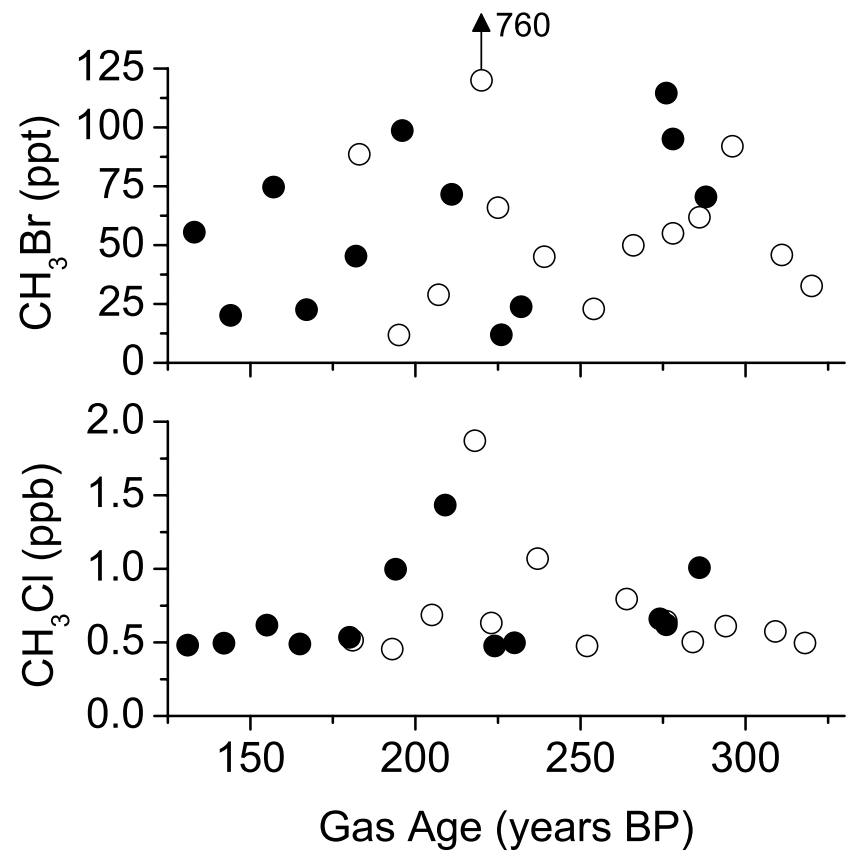

Figure 2. $\mathrm{CH}_{3} \mathrm{Cl}$ and $\mathrm{CH}_{3} \mathrm{Br}$ mixing ratios in Greenland ice core samples from the dry-drilled GISP2 B core $(\bullet)$ and the fluid-drilled GISP2 D core $(\mathrm{O})$. The $\mathrm{CH}_{3} \mathrm{Br}$ mixing ratio for the D core sample at $220 \mathrm{BP}$ is off-scale at $760 \mathrm{ppt}$. The scale of the y axis is set at $125 \mathrm{ppt}$ to better represent the data set as a whole. Error bars are shown only when they are larger than the symbols.

the current levels over the last few decades [Aydin et al., 2004; Butler et al., 1999; Kaspers et al., 2004; Trudinger et $a l ., 2004]$. Ice core measurements from Antarctica indicate that the average $\mathrm{CH}_{3} \mathrm{Cl}$ mixing ratio during the last 300 years was $499 \pm 28$ ppt [Aydin et al., 2004]. These measurements support the modern budget which asserts that the anthropogenic emission sources for $\mathrm{CH}_{3} \mathrm{Cl}$ are much smaller than the natural sources [Montzka et al., 2003a].

[30] The average $\mathrm{CH}_{3} \mathrm{Cl}$ mixing ratio measured in GISP2 ice cores is $705 \pm 339 \mathrm{ppt}$ (Table 2), exceeding both the mean level and variability observed in Antarctic ice cores (Figure 2). Despite the high mean value, the $\mathrm{CH}_{3} \mathrm{Cl}$ levels are around $500 \mathrm{ppt}$ during the youngest 60 years of the GISP2 record, in accord with what would be expected from firn records. However, there are several measurements greater than $600 \mathrm{ppt}$ and five scattered at or above $1 \mathrm{ppb}$ between 185 and $300 \mathrm{BP}$, suggesting that the data may be impacted by in situ $\mathrm{CH}_{3} \mathrm{Cl}$ production. If the elevated points are ignored, there appears to be a "baseline" $\mathrm{CH}_{3} \mathrm{Cl}$ level of about 500 ppt.

[31] Episodic in situ production may be linked to particulate deposition [Sturges et al., 2001a] or other environmental factors, such as extreme warming and melting events, that are linked to the ice itself rather than the air trapped in the bubbles. The ice ages of the samples with elevated $\mathrm{CH}_{3} \mathrm{Cl}$ measurements correspond to a 150 -year period between 1500 and $1650 \mathrm{AD}$ (approximate gas ages of 1700-1850 BP; Figure 2) that is marked by a warming climate at Summit, as evidenced by a $10 \%$ increase in the snow accumulation rate [Meese et al., 1994]. However, there are no melt layers [Meese et al., 1994] or obvious anomalies in ice chemistry [Mayewski et al., 1990, 1997; Taylor et al., 1996; Yang et al., 1995] that correlate with the elevated $\mathrm{CH}_{3} \mathrm{Cl}$ during this period. There is also no indication that the drill fluid has any effect on $\mathrm{CH}_{3} \mathrm{Cl}$ measurements (Figure 2). The B and D core averages are similar at $692 \pm 299$ and $717 \pm 384 \mathrm{ppt}$, respectively (Table 2), yet only three of the six sample pairs show good agreement between $\mathrm{B}$ and $\mathrm{D}$ cores. If in situ production is responsible for this scatter, the processes responsible do not appear to be continuous and ongoing since the highest measurements are concentrated in the middle of the record around $220 \mathrm{BP}$. It seems more likely that the production occurred in the firn or ended some time after bubble close off and that a warmer local climate might have triggered it. The results place doubts on the prospects of recovering a paleoatmospheric $\mathrm{CH}_{3} \mathrm{Cl}$ record from Greenland ice cores.

[32] $\mathrm{CH}_{3} \mathrm{Br}$ is a precursor of stratospheric ozone depleting bromine and has a tropospheric lifetime of 0.7 years [Colman et al., 1998; Kurylo et al., 1999; Shorter et al., 1995; Warwick et al., 2006; Yvon-Lewis and Butler, 1997]. Tropospheric $\mathrm{CH}_{3} \mathrm{Br}$ peaked at about $10.5 \mathrm{ppt}$ in the Northern Hemisphere during the late 1990's, with an interhemispheric gradient slightly higher than 2 ppt [Montzka et al., 2003b]. $\mathrm{CH}_{3} \mathrm{Br}$ levels have been dropping since then primarily because of the restrictions under the Montreal Protocol [Montzka et al., 2003b; Yokouchi et al., 2002]. Model simulations based on Antarctic firn air and ice core measurements suggest that preindustrial levels of $\mathrm{CH}_{3} \mathrm{Br}$ were lower in both hemispheres with a smaller interhemispheric gradient [Reeves, 2003; Saltzman et al., 2004].

[33] In the GISP ice cores, $\mathrm{CH}_{3} \mathrm{Br}$ levels are well above ambient levels and highly scattered, with an average mixing ratio of $83 \pm 144$ ppt (Table 2 and Figure 2). The data strongly suggest that $\mathrm{CH}_{3} \mathrm{Br}$ undergoes in situ enrichment similar to what has been found in Northern Hemisphere firn air [Butler et al., 1999; Sturges et al., 2001a]. The enrichment of $\mathrm{CH}_{3} \mathrm{Br}$ can exceed the ambient levels by more than an order of magnitude and it is not restricted to a particular section of the ice cores. There does appear to be some relationship between the enrichments of $\mathrm{CH}_{3} \mathrm{Br}$ and $\mathrm{CH}_{3} \mathrm{Cl}$. The minimum and maximum $\mathrm{D}$ core $\mathrm{CH}_{3} \mathrm{Br}$ measurements are 12 and 760 ppt at 195 and $220 \mathrm{BP}$, respectively, both measured in samples with extreme $\mathrm{CH}_{3} \mathrm{Cl}$ values. In the B core, the minimum $\mathrm{CH}_{3} \mathrm{Br}$ and $\mathrm{CH}_{3} \mathrm{Cl}$ values of 12 and $476 \mathrm{ppt}$ also occur in the same sample from $226 \mathrm{BP}$. The maximum $\mathrm{CH}_{3} \mathrm{Br}$ measurement from the $\mathrm{B}$ core is $115 \mathrm{ppt}$ at $276 \mathrm{BP}$, but the $\mathrm{CH}_{3} \mathrm{Cl}$ value for this sample is only slightly elevated at 660 ppt. For all 25 data points, omitting one very high measurement for both compounds at $220 \mathrm{BP}$, the correlation coefficient between $\mathrm{CH}_{3} \mathrm{Br}$ and $\mathrm{CH}_{3} \mathrm{Cl}$ is 0.37 with a $\mathrm{p}$ value of 0.072 , not showing significance at $95 \%$ level. There is likely more than one mechanism that leads to the production of methyl halides, as the enrichment of the brominated species appears to be more widespread.

\subsection{Carbonyl Sulfide and Carbon Disulfide}

[34] OCS is the most abundant sulfur species in the troposphere with a mixing ratio of about $500 \mathrm{ppt}$ and a 

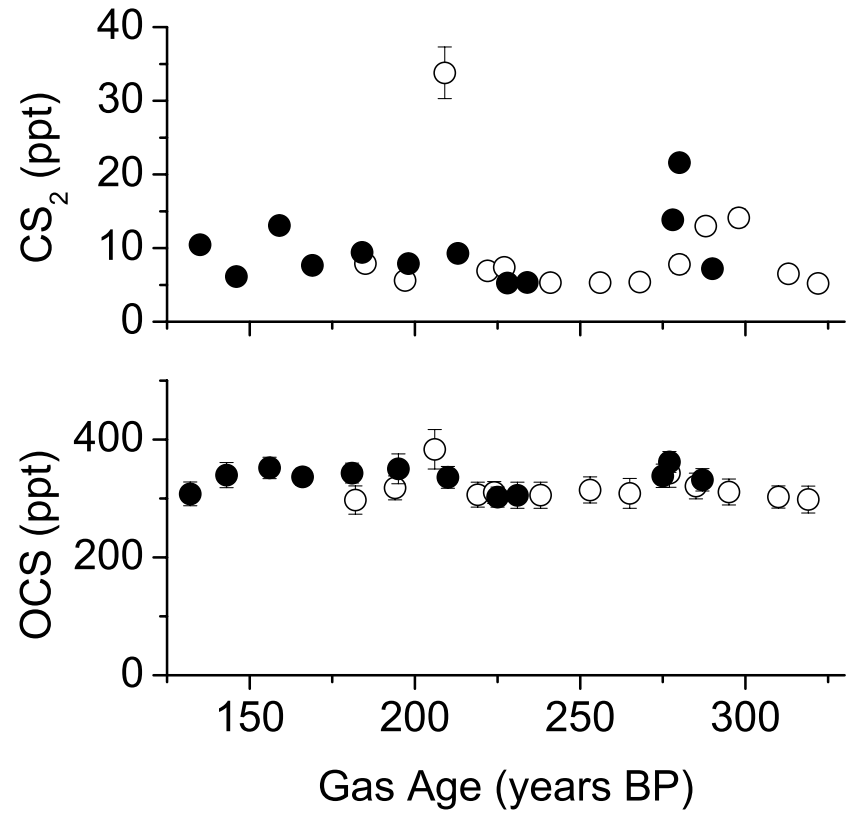

Figure 3. OCS and $\mathrm{CS}_{2}$ mixing ratios in Greenland ice core samples from the dry-drilled GISP2 B core $(\bullet)$ and the fluid-drilled GISP2 D core $(O)$. Error bars are shown only when they are larger than the symbols.

lifetime of 2-4 years [Chin and Davis, 1995; Montzka et al., in print, JGR 2006]. Results of the first OCS measurements in firn air from Canada and Antarctica suggest that this compound is stable in the firn with middle to late twentieth century levels scattered around $500 \mathrm{ppt}$ in both hemispheres [Sturges et al., 2001b]. Subsequent measurements in Antarctic firn air and ice cores extended the length of the record to 350 years, with OCS levels varying between 300 and 400 ppt [Aydin et al., 2002; Montzka et al., 2004].

[35] The results from GISP B and D cores display steady OCS levels with a mean of $325 \pm 23$ ppt for the Northern Hemisphere between 125 and 325 BP (Table 2 and Figure 3). The OCS levels between 215 and 270 BP are marginally lower than the rest at 300-310 ppt. The data from both cores agree within errors where they overlap, suggesting that the OCS signal in the GISP cores is robust.

[36] In Figure 4, the OCS data from the GISP core are compared with the 350 year record from a Siple Dome Antarctic ice core [Montzka et al., 2004]. The overall agreement between the Greenland and Antarctic OCS records strongly suggest that ice cores from both hemispheres can be used to develop paleo records for this trace gas over centennial timescales. Between 300 and $320 \mathrm{BP}$, Antarctic OCS levels are about 75-100 ppt greater than those measured at Greenland (Figure 4). If confirmed by other ice cores, such an interhemispheric gradient would likely indicate either an increase in the Southern Hemisphere oceanic source or a decrease in the Northern Hemisphere terrestrial sink during this period.

[37] $\mathrm{CS}_{2}$ is a precursor to atmospheric OCS, with both natural and anthropogenic sources and an atmospheric lifetime of several days. Ambient levels of $\mathrm{CS}_{2}$ in marine air are typically in the range of $0.5-10 \mathrm{ppt}$, although there are relatively few measurements to date [Bandy et al., 1993; Johnson and Bates, 1993; Kim and Andreae, 1992; Kim and Andreae, 1987; Tucker et al., 1985]. Over the central and eastern North Pacific where the effects of the anthropogenic emissions diminish, $\mathrm{CS}_{2}$ levels are close to $4 \mathrm{ppt}$ in the boundary layer and drop to about $2 \mathrm{ppt}$ at $4 \mathrm{~km}$ altitude [Blake et al., 2004]. $\mathrm{CS}_{2}$ levels in the GISP ice core samples are similar to those in ambient air with an overall average of $10 \pm 6$ ppt (Table 2 and Figure 3 ). There is reasonably good agreement between the two cores, with the notable exception of an outlier from the D core with a mixing ratio of 34 ppt at 209 BP. The OCS measurement for this sample also looks slightly anomalous. In our laboratory, $\mathrm{CS}_{2}$ contamination is usually accompanied by elevated OCS levels. We attribute this to contamination from sulfur cross-linked polymers. In the ice core samples, most of the samples with higher than average $\mathrm{CS}_{2}$ levels are apparently not associated with elevated OCS. It is possible that there is a stronger emission of $\mathrm{CS}_{2}$ from the contamination source, or the OCS contamination is masked by its relatively high abundance. Contamination at low ppt levels can essentially remain less than the measurement uncertainty against an OCS background that is at $300 \mathrm{ppt}$ and above.

[38] Current budget estimates for $\mathrm{CS}_{2}$ suggest that the oceans should be the dominant source of $\mathrm{CS}_{2}$ to the preindustrial atmosphere [Andreae and Ferek, 1992; Chin and Davis, 1993; Kettle et al., 2002; Kjellström, 1998; Watts, 2000]. Although their atmospheric lifetimes are very different, one might expect some correlation between the atmospheric levels of OCS and $\mathrm{CS}_{2}$. It is interesting that the lowest OCS mixing ratios in the GISP record are roughly from the same time period between 215 and $275 \mathrm{BP}$ as the lowest $\mathrm{CS}_{2}$ measurements (Figure 3). Currently, there are no firn or surface air measurements of $\mathrm{CS}_{2}$ from Summit, Greenland with which the ice core measurements can be compared. However, the data them-

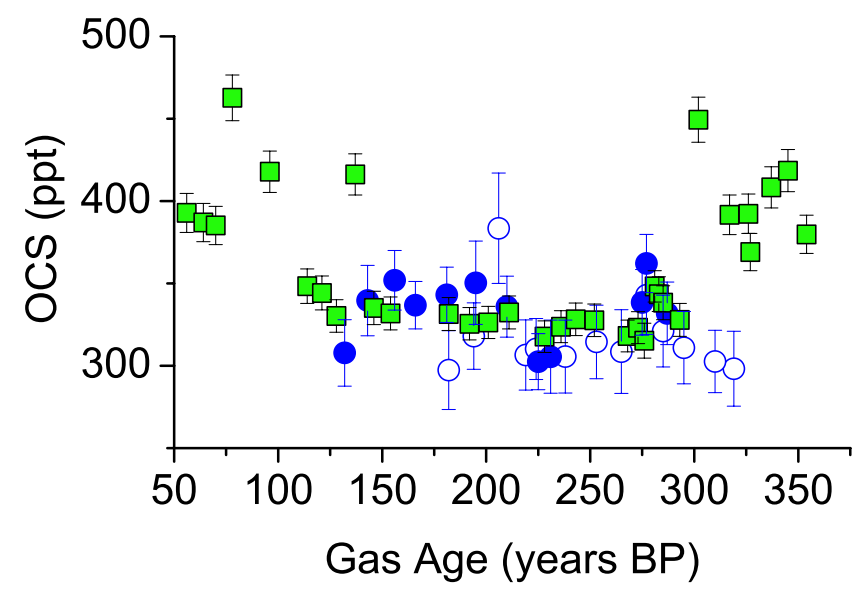

Figure 4. OCS mixing ratios in contemporaneous Greenland and Antarctic ice core samples. Ice core samples from the dry-drilled GISP2 B core $(\bullet)$, the fluid-drilled GISP2 D core $(\bigcirc)$, and the dry-drilled Siple Dome C core ( $\square$ ); [Aydin et al., 2002; Montzka et al., 2004]. 
selves are consistent with an atmospheric origin of the ice core $\mathrm{CS}_{2}$ signal.

\section{Conclusions}

[39] This study demonstrates the successful extraction and analysis of several short-lived trace gas species in Greenland ice cores. For all the gases measured, the signal derived from air extracted from ice core bubbles is above our detection limits. Only a few of the $\mathrm{C}_{3} \mathrm{H}_{8}$ and $n-\mathrm{C}_{4} \mathrm{H}_{10}$ samples appear to be elevated because of drill-fluid contamination. In future studies, the presence of drill fluid in the ice core samples can probably be minimized by careful sample selection. Monitoring additional hydrocarbons that are more sensitive to drill-fluid contamination could facilitate detection and possibly quantification of the drill-fluid contamination.

[40] The interpretation of the alkane measurements is challenging. Overall, the alkane mixing ratios in the ice are consistent with those in the modern Arctic atmosphere, and do not provide a priori evidence of in situ production. However, a paleoatmospheric interpretation of the data conflicts with current atmospheric budgets of the alkanes. Emissions because of natural gas and oil use are thought to constitute a major part of the total burden [Boissard et al., 1996; Katzenstein et al., 2003; Rudolph, 1995], suggesting that there should have been lower atmospheric levels during preindustrial times. We consider the origin of the current levels of alkanes in Greenland ice to be an open issue, which will require additional measurements to resolve.

[41] The methyl halide measurements indicate that in situ production processes, rather than paleoatmospheric levels, dominate the $\mathrm{CH}_{3} \mathrm{Br}$ signal in GISP ice cores and may influence to a lesser extent the ice core record of $\mathrm{CH}_{3} \mathrm{Cl}$. The GISP2 OCS measurements are in good agreement with those from Antarctic ice cores, and it appears likely that the ice core signals reflect paleoatmospheric mixing ratios. This raises the possibility of reconstructing a record of the interhemispheric gradient for OCS. The OCS budgets in the two hemispheres are quite different, with terrestrial processes dominating in the north and oceanic processes controlling in the south [Chin and Davis, 1993; Kettle et al., 2002; Kjellström, 1998; Watts, 2000]. The land sink for atmospheric OCS is related to gross primary productivity [Montzka et al., in press, JGR 2007] through uptake by plants [Goldan et $a l ., 1988$ ], and the Greenland ice core record may provide insight into the variability of the Northern Hemisphere terrestrial biosphere on short timescales. The $\mathrm{CS}_{2}$ measurements in the GISP cores appear reasonable in light of current atmospheric levels, but our knowledge of the modern atmospheric distribution of this compound is insufficient to draw a firm conclusion as to the origin of this signal.

[42] Acknowledgments. We would like to thank all PIs, the scientific staff, and the drilling team that contributed to the realization of the GISP project. We also would like to thank National Ice Core Laboratories for their assistance in sampling the GISP cores and Stephen A. Montzka for insightful discussions. This work was supported by NSF-Office of Polar Programs grant OPP0221480 and by the Gary Comer Science and Education Foundation.

\section{References}

Alley, R. B., et al. (1993), Abrupt increase in Greenland snow accumulation at the end of the Younger Dryas event, Nature, 362, 527-529.
Anderson, B. E., J. E. Collins, Jr., G. W. Sachse, G. W. Whiting, D. R. Blake, and F. S. Rowland (1993), AASE-II observations of trace carbon species distributions in the mid to upper troposphere, Geophys. Res. Lett., 20, 2539-2542.

Andreae, M. Ö., and R. R. Ferek (1992), Photochemical production of carbonyl sulfide in seawater and its emissions to the atmosphere, Global Biogeochem. Cycles, 6, 175-183.

Aydin, M., W. J. DeBruyn, and E. S. Saltzman (2002), Preindustrial atmospheric carbonyl sulfide (OCS) from an Antarctic ice core, Geophys. Res. Lett., 2(9), 1359, doi:10.1029/2002GL014796.

Aydin, M., W. J. DeBruyn, E. S. Saltzman, S. A. Montzka, and J. H. Butler (2004), Atmospheric variability of methyl chloride during the last 300 years from an Antarctic ice core and firn air, Geophys. Res. Lett., 31, L02109, doi:10.1029/2003GL018750.

Bandy, A. R., D. C. Thornton, and J. E. Johnson (1993), Carbon disulfide measurements in the atmosphere of the western North Atlantic and the northwestern South Atlantic Oceans, J. Geophys. Res., 98(D12), 23,44923,457 .

Blake, N. J., D. R. Blake, B. C. Sive, A. S. Katzenstein, S. Meinardi, O. W. Wingenter, E. L. Atlas, F. Flocke, B. A. Ridley, and F. S. Rowland (2003), The seasonal evolution of NMHCs and light alkyl nitrates at middle to high northern latitudes during TOPSE, J. Geophys. Res., 108(D4), 8359, doi:10.1029/2001JD001467.

Blake, N. J., et al. (2004), Carbonyl sulfide and carbon disulfide: Large-scale distributions over the western Pacific and emissions from Asia during TRACE-P, J. Geophys. Res., 109(D15S05), doi:10.1029/ 2003JD004259.

Boissard, C., B. Bonsang, M. Kanakidou, and G. Lambert (1996), TROPOZ II: Global distributions and budgets of methane and light hydrocarbons, J. Atmos. Chem., 25(2), 115-148.

Butler, J. H., M. Battle, M. L. Bender, S. A. Montzka, A. D. Clarke, E. S. Saltzman, C. M. Sucher, J. P. Severinghaus, and J. W. Elkins (1999), A record of atmospheric halocarbons during the twentieth century from polar firn air, Nature, 399, 749-755.

Chin, M., and D. D. Davis (1993), Global sources and sinks of OCS and $\mathrm{CS}_{2}$ and their distributions, Global Biogeochem. Cycles, 7, 321-337.

Chin, M., and D. D. Davis (1995), A reanalysis of carbonyl sulfide as a source of stratospheric background sulfur aerosol, J. Geophys. Res., 100(D5), 8993-9006.

Colman, J. J., D. R. Blake, and F. S. Rowland (1998), Atmospheric residence time of $\mathrm{CH} 3 \mathrm{Br}$ estimated from the Junge spatial variability relation, Science, 281, 392-396.

Engen, M. A., V. A. Wagner, L. J. Sears, and E. P. Grimsrud (1998), Detection of $\mathrm{CF}_{3}$-containing compounds in background air by gas chromatography/high-resolution mass spectrometry, J. Geophys. Res., 103, 25,287-25,297.

Engen, M. A., J. A. Culbertson, and E. P. Grimsrud (1999), Analysis of brominated compounds in background air by gas chromatography-high resolution mass spectrometry, J. Chromatogr., A, 848, 261-277.

Etheridge, D. M., G. I. Pearman, and F. de Silva (1988), Atmospheric tracegas variations as revealed by air trapped in an ice core from Law Dome, Antarctica, Ann. Glaciol., 10, 28-33.

Gautrois, M., T. Brauers, R. Koppmann, F. Rohrer, O. Stein, and J. Rudolph (2003), Seasonal variability and trends of volatile organic compounds in the lower polar troposphere, J. Geophys. Res., 108(D13), 4393, doi:10.1029/2002JD002765.

Goldan, P. D., R. Fall, W. C. Kuster, and F. C. Fehsenfeld (1988), Uptake of COS by growing vegetation: A major tropospheric sink, J. Geophys. Res., 93, 14,186-14,192.

Jobson, B. T., H. Niki, Y. Yokouchi, J. Bottenheim, F. Hopper, and R. Leaitch (1994), Measurements of $C_{2}-C_{6}$ hydrocarbons during the Polar Sunrise 1992 Experiment: Evidence for $\mathrm{Cl}$ atom and $\mathrm{Br}$ atom chemistry, J. Geophys. Res., 99(D12), 25,355-25,368.

Johnson, J. E., and T. S. Bates (1993), Atmospheric measurements of carbonyl sulfide, dimethyl sulfide, and carbon disulfide using the electron capture sulfur detector, J. Geophys. Res., 98(D12), 23,411-23,421.

Kanakidou, M., K. M. Valentin, P. J. Crutzen, and H. B. Singh (1991), A two-dimensional study of ethane and propane oxidation in the troposphere, J. Geophys. Res., 96, 15,395-15,413.

Kaspers, K. A., et al. (2004), Analyses of firn gas samples from Dronning Maud Land, Antarctica: Study of nonmethane hydrocarbons and methyl chloride, J. Geophys. Res., 109(D2), D02307, doi:10.1029/ 2003JD003950.

Katzenstein, A. S., L. A. Doezema, I. J. Simpson, D. R. Blake, and F. S.Rowland (2003), Extensive regional atmospheric hydrocarbon pollution in the southwestern United States, Proc. Natl. Acad. Sci. U. S. A., 100(21), 11,975-11,979.

Keene, W. C., et al. (1996), Composite global emissions of reactive chlorine from anthropogenic and natural sources: Reactive chlorine emissions inventory, J. Geophys. Res., 104, 8429-8440. 
Kettle, A. J., U. Kuhn, M. von Hobe, J. Kesselmeier, and M. Ö. Andreae (2002), Global budget of atmospheric carbonyl sulfide: Temporal and spatial variations of the dominant sources and sinks, J. Geophys. Res. 107(D22), 4658, doi:10.1029/2002JD002187.

Khalil, M. A. K., and R. A. Rasmussen (1999), Atmospheric methyl chloride, Atmos. Environ., 33, 1305-1321.

Khalil, M. A. K., and R. A. Rasmussen (2000), Soil-atmosphere exchange of radiatively and chemically active gases, Environ. Sci. Pollut. Res. Int. 7, $79-82$.

Kim, K.-H., and M. Ö. Andreae (1987), Carbon disulfide in seawater and the marine atmosphere over the North Atlantic, J. Geophys. Res., 92, $14,733-14,738$.

Kim, K.-H., and M. Ö. Andreae (1992), Carbon disulfide in the estuarine, coastal, and oceanic environments, Mar. Chem., 40, 179-197.

Kjellström, E. (1998), A three-dimensional global model study of Carbonyl Sulfide in the troposphere and the lower stratosphere, J. Atmos. Chem., 29, $151-177$

Kurylo, M. J., et al. (1999), Short-lived ozone-related compounds, in Scientific Assessment of Ozone Depletion: 1998, chapter 2, Global Ozone Research and Monitoring Project-Report 44, World Meteorological Organization, Geneva.

Laurila, T., and H. Hakola (1996), Seasonal cycle of $\mathrm{C}_{2}-\mathrm{C}_{5}$ hydrocarbons over the Baltic Sea and northern Finland, Atmos. Environ., 30(10/11), $1597-1607$

Lindskog, A., and J. Moldanova (1994), The influence of the origin, season, and time of the day on the distribution of individual NMHC measured at Rorvik, Sweden, Atmos. Environ., 28(15), 2383-2398.

Mayewski, P. A., W. B. Lyons, M. J. Spencer, M. S. Twickler, C. F. Buck, and S. I. Whitlow (1990), An ice core record of atmospheric response to anthropogenic sulphate and nitrate, Nature, 346, 554-556.

Mayewski, P. A., L. D. Meeker, M. S. Twickler, S. I. Whitlow, Q. Yang, W. B. Lyons, and M. Prentice (1997), Major features and forcing of highlatitude Northern Hemisphere atmospheric circulation using a 110,000 year-long glaciochemical series, J. Geophys. Res., 102, 26,345-26,366.

Meese, D. A., A. J. Gow, P. Grootes, P. A. Mayewski, M. Ram, M. Stuiver, K. C. Taylor, E. D. Waddington, and G. A. Zielinski (1994), The accumulation record from the GISP2 core as an indicator of climate change through the Holocene, Science, 266(5191), 1680-1682.

Montzka, S. A., et al. (2003a), Controlled substances and other source gases, in Scientific Assessment of Ozone Depletion: 2002, chapter 1, Global Ozone Research and Monitoring Project-Report 47, World Meteorological Organization, Geneva.

Montzka, S. A., J. H. Butler, B. D. Hall, D. J. Mondeel, and J. W. Elkins (2003b), A decline in tropospheric organic bromine, Geophys. Res. Lett., 30(15), 1826, doi:10.1029/2003GL017745.

Montzka, S. A., M. Aydin, J. H. Butler, M. Battle, E. S. Saltzman, G. S. Dutton, B. D. Hall, A. D. Clarke, D. Mondeel, and J. W. Elkins (2004), A 350-year atmospheric history for carbonyl sulfide inferred from Antarctic firn air and air trapped in ice, J. Geophys. Res., 109 (D22302), doi:10.1029/2004JD004686.

Moore, R. M., W. Groszko, and S. J. Niven (1996), Ocean-atmosphere exchange of methyl chloride: Results from NW Atlantic and Pacific Ocean studies, J. Geophys. Res., 101, 28,529-28,538.

Olivier, J. G. J., A. F. Bouwman, C. W. M. Van der Maas, J. J. M. Berdowski, C. Veldt, J. P. J. Bloos, A. J. H. Visschedijk, P. Y. J. Zandveld, and J. L. Haverlag (1996), Description of EDGAR Version 2.0: A set of global emission inventories of greenhouse gases and ozone-depleting substances for all anthropogenic and most natural sources on a per country basis and on $1^{\circ} \times 1^{\circ}$ grid, National Institute of Public Health and the Environment (RIVM), Bilthoven, Report 771060 002/TNO-MEP report R96/110.

Penkett, S. A., N. J. Blake, P. Lightman, A. R. W. Marsh, P. Anwyl, and G. Butcher (1993), The seasonal variation of non-methane hydrocarbons in the free troposphere over the North Atlantic Ocean: Possible evidence for extensive reaction of hydrocarbons with the nitrate radical, J. Geophys. Res., 98, 2865-2885.

Poisson, N., M. Kanakidou, and P. J. Crutzen (2000), Impact of NMHCs on tropospheric chemistry and the oxidizing power of the global troposphere: 3-dimensional modeling results, J. Atmos. Chem., 36, 157-230.

Reeves, C. (2003), Atmospheric budget implications of the temporal and spatial trends in methyl bromide concentration, J. Geophys. Res., 108(D11), 4343, doi:10.1029/2002JD002943.
Rudolph, J. (1995), The tropospheric distribution and budget of ethane, J. Geophys. Res., 100(D6), 11,369-11,381.

Saito, T., Y. Yokouchi, S. Aoki, T. Nakazawa, Y. Fujii, and O. Watanabe (2006), A method for determination of methyl chloride concentration in air trapped in ice cores, Chemosphere, 63, 1209-1213.

Saltzman, E. S., M. Aydin, W. J. DeBruyn, D. B. King, and S. A. YvonLewis (2004), Methyl bromide in preindustrial air: Measurements from an Antarctic ice core, J. Geophys. Res., 109(D05301), doi:10.1029/ 2003JD004157.

Schwander, J., J. M. Barnola, C. Andrie, M. Leuenberger, A. Ludin, D. Raynaud, and B. Stauffer (1993), The age of the air in the firn and ice at Summit, Greenland, J. Geophys. Res., 98, 2831-2838.

Schwander, J., T. Sowers, J.-M. Barnola, T. Blunier, A. Fuchs, and B. Malaize (1997), Age scale of the air in the summit ice: Implication for glacial-interglacial temperature change, J. Geophys. Res., 102(D16), $19,483-19,493$

Shorter, J. H., C. E. Kolb, P. M. Crill, R. A. Kerwin, R. W. Talbot, M. E. Hines, and R. C. Harriss (1995), Rapid degradation of atmospheric methyl bromide in soils, Nature, 377, 717-719.

Sowers, T., and J. Jubenville (2000), A modified extraction technique for liberating occluded gases from ice cores, J. Geophys. Res., 105, 29,15529,164 .

Sturges, W. T., H. P. McIntyre, S. A. Penkett, J. A. Chappellaz, J.-M. Barnola, R. Mulvaney, E. Atlas, and V. Stroud (2001a), Methyl bromide, other brominated methanes and methyl iodide in polar firn air, J. Geophys. Res., 106, 1595-1606.

Sturges, W. T., S. A. Penkett, J. M. Barnola, J. Chappellaz, E. Atlas, and V. Stroud (2001b), A long-term measurement record of carbonyl sulfide (COS) in two hemispheres from firn air measurements, Geophys. Res. Lett., 28, 4095-4098.

Swanson, A. L., N. J. Blake, J. E. Dibb, M. A. Albert, D. R. Blake, and F. S. Rowland (2002), Photochemically induced production of $\mathrm{CH}_{3} \mathrm{Br}, \mathrm{CH}_{3} \mathrm{I}, \mathrm{C}_{2} \mathrm{H}_{5} \mathrm{I}$, ethene, and propene within surface snow, Atmos. Environ., 36, 2671-2682.

Taylor, K. C., P. A. Mayewski, M. S. Twickler, and S. I. Whitlow (1996), Biomass burning recorded in the GISP2 ice core: A record from eastern Canada?, Holocene, 6(1), 1-6.

Trudinger, C. M., D. M. Etheridge, G. A. Sturrock, P. J. Fraser, P. B. Krummel, and A. McCulloch (2004), Atmospheric histories of halocarbons from analysis of Antarctic firn air: Methyl bromide, methyl chloride, chloroform, and dichloromethane, J. Geophys. Res., 109 (D22310), doi:10.1029/2004JD004932.

Tucker, B. J., P. J. Maroulis, and A. R. Bandy (1985), Free tropospheric measurements of $\mathrm{CS} 2$ over a $45^{\circ} \mathrm{N}$ to $45^{\circ} \mathrm{S}$ latitude range, Geophys. Res. Lett., 12, 9-11.

Walker, S. J., R. F. Weiss, and P. K. Salameh (2000), Reconstructed histories of the annual mean atmospheric mole fractions for the halocarbons CFC-11, CFC-12, CFC-113 and carbon tetrachloride, J. Geophys. Res., 105, 14,285-14,296.

Warwick, N. J., J. A. Pyle, and D. E. Shallcross (2006), Global modeling of the Atmospheric Methyl Bromide Budget, J. Atmos. Chem., 54, $133-$ 159

Watts, S. F. (2000), The mass budgets of carbonyl sulfide, dimethyl sulfide, carbon disulfide and hydrogen sulfide, Atmos. Environ., 34, 761-779.

Worton, D. R. (2006), Alkyl nitrates (C1-C5), trihalomethanes and related compounds in contemporary air and air preserved in polar firn and ice, Ph.D. thesis, University of East Anglia, Norwich, UK.

Yang, Q., P. A. Mayewski, S. I. Whitlow, M. S. Twickler, M. C. Morrison, R. W. Talbot, J. E. Dibb, and E. Linder (1995), Global perspective of nitrate flux in ice cores, J. Geophys. Res., 100, 5113-5121.

Yokouchi, Y., D. Toom-Saundry, K. Yazawa, T. Inagaki, and T. Tamaru (2002), Recent decline of methyl bromide in the troposphere, Atmos. Environ., 36, 4985-4989.

Yvon-Lewis, S. A., and J. H. Butler (1997), The potential effect of biological degradation on the lifetime of atmospheric $\mathrm{CH}_{3} \mathrm{Br}$, Geophys. Res. Lett., 24, 1227-1230.

M. Aydin, E. S. Saltzman, and M. B. Williams, Department of Earth System Science, University of California, Croul Hall 3206, Irvine, CA 92697, USA. (maydin@uci.edu) 